\title{
Chemical isolation in the Asian monsoon anticyclone observed in Atmospheric Chemistry Experiment (ACE-FTS) data
}

\author{
M. Park ${ }^{1}$, W. J. Randel ${ }^{1}$, L. K. Emmons ${ }^{1}$, P. F. Bernath ${ }^{2,3}$, K. A. Walker ${ }^{2, *}$, and C. D. Boone ${ }^{2}$ \\ ${ }^{1}$ National Center for Atmospheric Research, Boulder, Colorado, USA \\ ${ }^{2}$ Department of Chemistry, University of Waterloo, Waterloo, Ontario, Canada \\ ${ }^{3}$ Department of Chemistry, University of York, Heslington, York, UK \\ *now at: Department of Physics, University of Toronto, Toronto, Ontario, Canada
}

Received: 2 August 2007 - Published in Atmos. Chem. Phys. Discuss.: 25 September 2007

Revised: 8 January 2008 - Accepted: 16 January 2008 - Published: 14 February 2008

\begin{abstract}
Evidence of chemical isolation in the Asian monsoon anticyclone is presented using chemical constituents obtained from the Atmospheric Chemistry Experiment Fourier Transform Spectrometer instrument during summer (June-August) of 2004-2006. Carbon monoxide (CO) shows a broad maximum over the monsoon anticyclone region in the upper troposphere and lower stratosphere (UTLS); these enhanced CO values are associated with air pollution transported upward by convection, and confined by the strong anticyclonic circulation. Profiles inside the anticyclone show enhancement of tropospheric tracers $\mathrm{CO}$, $\mathrm{HCN}, \mathrm{C}_{2} \mathrm{H}_{6}$, and $\mathrm{C}_{2} \mathrm{H}_{2}$ between $\sim 12$ to $20 \mathrm{~km}$, with maxima near $13-15 \mathrm{~km}$. Strong correlations are observed among constituents, consistent with sources from near-surface pollution and biomass burning. Stratospheric tracers $\left(\mathrm{O}_{3}, \mathrm{HNO}_{3}\right.$ and $\mathrm{HCl}$ ) exhibit decreased values inside the anticyclone between $\sim 12-20 \mathrm{~km}$. These observations are further evidence of transport of lower tropospheric air into the UTLS region, and isolation of air within the anticyclone. The relative enhancements of tropospheric species inside the anticyclone are closely related to the photochemical lifetime of the species, with strongest enhancement for shorter lived species. Vertical profiles of the ratio of $\mathrm{C}_{2} \mathrm{H}_{2} / \mathrm{CO}$ (used to measure the relative age of air) suggest relatively rapid transport of fresh emissions up to the tropopause level inside the anticyclone.
\end{abstract}

\section{Introduction}

The Asian summer monsoon is the dominant circulation feature spanning Southeast Asia to Afghanistan during Northern Hemisphere (NH) summer. The Asian monsoon circu-

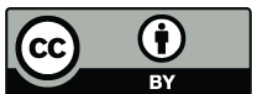

Correspondence to: M. Park (mijeong@ucar.edu) lation is a thermally direct circulation dominated by a lowlevel thermal low and an upper-level anticyclone (Krishnamurti and Bhalme, 1976). Flanked by the equatorial and subtropical jets, the anticyclone acts as strong transport barrier to chemical constituents, such as water vapor (Dethof et al., 1999) and ozone (Randel and Park, 2006), in the upper troposphere and lower stratosphere (UTLS). Carbon monoxide transported upwards by the monsoon convection is trapped within the monsoon anticyclone in the upper troposphere ( $\mathrm{Li}$ et al., 2005). Recent satellite observations have highlighted the strong isolation of carbon monoxide within the monsoon anticyclone, extending into the lower stratosphere (Fu et al., 2006; Park et al., 2007).

The Atmospheric Chemistry Experiment (ACE) is a Canadian-led satellite mission launched in 2003. The ACE Fourier Transform Spectrometer (ACE-FTS) instrument provides vertical profiles of a few dozen chemical species covering the middle troposphere to thermosphere $(\sim 10-100 \mathrm{~km})$, with data available from the polar regions to the tropics (Bernath et al., 2005). In this study we use ACE-FTS measurements to explore the consequences of vertical transport within the Asian monsoon anticyclone. In particular, we focus on the ACE-FTS measurements of carbon monoxide $(\mathrm{CO})$, hydrogen cyanide $(\mathrm{HCN})$, ethane $\left(\mathrm{C}_{2} \mathrm{H}_{6}\right)$ and acetylene $\left(\mathrm{C}_{2} \mathrm{H}_{2}\right)$, which have common sources of biomass burning (Andreae and Merlet, 2001) and major sinks of reaction with hydroxyl radical (Logan et al., 1981). The photochemical lifetimes of these species span the range of 0.5 5 months, which make them useful as tracers of transport in the troposphere and lower stratosphere. We also include analyses of methyl chloride $\left(\mathrm{CH}_{3} \mathrm{Cl}\right)$, which is produced by biomass burning and has a lifetime of about a year (Blake et al., 1996; Yoshida et al., 2004), and carbonyl sulfide (OCS), with sources of anthropogenic and oceanic emissions (Watts, 2000) and a lifetime of several years (Chin and Davis, 1995; Blake et al., 2004). 
Table 1. Photochemical lifetimes.

\begin{tabular}{ll}
\hline Species & Lifetime \\
\hline $\mathrm{CO}$ & $2-3$ months $^{\mathrm{a}}$ \\
$\mathrm{HCN}$ & 5 months ${ }^{\mathrm{c}, \mathrm{d}, \mathrm{e}}$ \\
$\mathrm{C}_{2} \mathrm{H}_{6}$ & $1-2$ months $^{\mathrm{b}, \mathrm{d}}$ \\
$\mathrm{C}_{2} \mathrm{H}_{2}$ & $0.5-1$ months \\
$\mathrm{CH}_{3} \mathrm{Cl}$ & 1 year \\
$\mathrm{OCS}, \mathrm{f}, \mathrm{i}$ \\
$\mathrm{OCS}$ & 4.3 years $^{\mathrm{g}, \mathrm{h}}$
\end{tabular}

a Xiao et al., 2007

${ }^{\mathrm{b}}$ Logan et al., 1981

${ }^{\mathrm{c}} \mathrm{Li}$ et al., 2000

d Zhao et al., 2002

e Singh et al., 2003

f Blake et al., 1996

g Blake et al., 2004

${ }^{\mathrm{h}}$ Chin and Davis, 1996

${ }^{\mathrm{i}}$ Yoshida et al., 2004
Numerous observational studies of tropospheric pollutants have been made based on aircraft observations (e.g., Smyth et al., 1996; Blake et al., 1996; Talbot et al., 1999; Singh et al., 2003; Russo et al., 2003). However, space-based observations are limited and relatively new. Tropospheric $\mathrm{CO}$ has been obtained from several satellite instruments, including Measurement of Air Pollution from Satellites (Connors et al., 1999), Interferometric Monitor for Greenhouse gases (Clerbaux et al., 2003), Measurements Of Pollution In The Troposphere (Deeter et al., 2004; Edwards et al., 2006), Microwave Limb Sounder (Waters et al., 2006), and Tropospheric Emission Spectrometer (Beer, 2006), and these data have been used for studies of tropospheric pollution and long-range transport. However, ACE-FTS has the advantage of simultaneous retrieval of numerous species in addition to $\mathrm{CO}$. A few previous studies have used ACE-FTS measurements of $\mathrm{CO}$, $\mathrm{HCN}, \mathrm{C}_{2} \mathrm{H}_{6}, \mathrm{C}_{2} \mathrm{H}_{2}$, and methanol $\left(\mathrm{CH}_{3} \mathrm{OH}\right)$ to study the effect of biomass burning emissions in the UTLS region (Rinsland et al., 2005; Dufour et al., 2006; Coheur et al., 2007), and our work extends those analyses with focus on the Asian monsoon region.

\section{Data description}

The ACE mission was launched on 12 August 2003 into a high inclination $\left(74^{\circ}\right)$ circular orbit at $650 \mathrm{~km}$ altitude. The high resolution infrared ACE-FTS measures solar absorption spectra from 750 to $4400 \mathrm{~cm}^{-1}$ using the solar occultation technique. The primary goal of the ACE mission is focused on polar ozone chemistry and dynamics, and the majority of measurements are obtained over high latitudes (Bernath et al., 2005). The vertical field of view of the instrument is $3 \mathrm{~km}$, and measurements during each occultation are obtained with a vertical sampling of $2-6 \mathrm{~km}$ (depending on the angle of the sun with respect to the spacecraft velocity vector); the constituent profile retrievals are available on a (oversampled) $1 \mathrm{~km}$ vertical grid (Boone et al., 2005). The data here are based on version 2.2 retrievals (including the updated ozone). The $\mathrm{C}_{2} \mathrm{H}_{6}$ and $\mathrm{C}_{2} \mathrm{H}_{2}$ data are research products retrieved to higher altitudes (up to $21 \mathrm{~km}$ for $\mathrm{C}_{2} \mathrm{H}_{6}$ and $18 \mathrm{~km}$ for $\mathrm{C}_{2} \mathrm{H}_{2}$ ) for this study, and we focus on observations
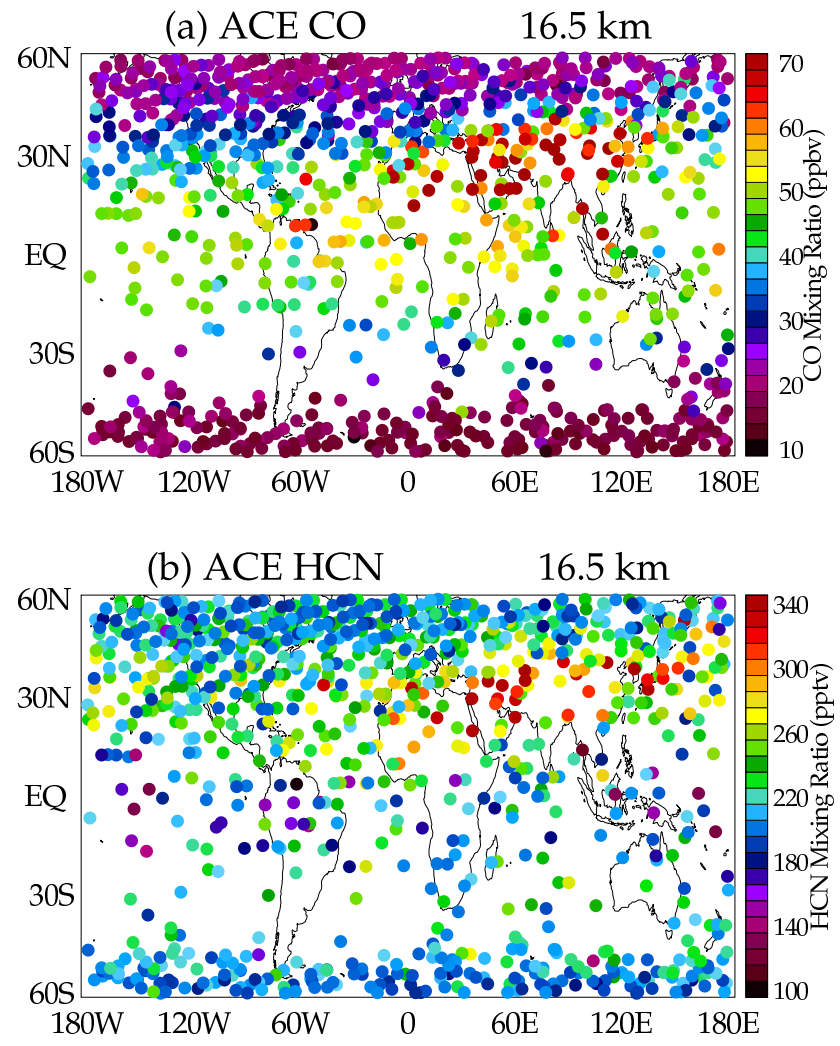

Fig. 1. Global map of (a) $\mathrm{CO}$ and (b) $\mathrm{HCN}$ mixing ratios at $16.5 \mathrm{~km}$ for June-August (2004-2006). Approximate data range is 10-70 parts per billion by volume (ppbv) for CO and 100-340 parts per trillion by volume (pptv) for $\mathrm{HCN}$.

during NH summer (June-August) of 2004-2006. Due to the orbit geometry, most of the low latitude observations occur in August during this period.

The chemical species analyzed here include tropospheric constituents $\mathrm{CO}, \mathrm{HCN}, \mathrm{C}_{2} \mathrm{H}_{6}, \mathrm{C}_{2} \mathrm{H}_{2}$, OCS, and $\mathrm{CH}_{3} \mathrm{Cl}$, and stratospheric species $\mathrm{O}_{3}, \mathrm{HNO}_{3}$, and $\mathrm{HCl}$. The photochemical lifetimes of these constituents, which span the range from $\sim 1$ month to longer than 1 year, are provided in Table 1 . These numbers are estimated in the troposphere but are almost constant up to the UTLS region. For data screening purposes, we exclude profiles with values outside of threesigma variance between $60^{\circ} \mathrm{S}$ and $60^{\circ} \mathrm{N}$. This method typically excludes less than $1 \%$ of profiles depending on the species. The estimated fitting errors of version 2.2. $\mathrm{CO}$ and version 2.2 updated ozone are $2-6 \%$ and $2-7 \%$ in the UTLS region, respectively. The $\mathrm{CO}$ retrieval errors are better than $5 \%$ from the upper troposphere to $40 \mathrm{~km}$ (Clerbaux et al., 2007). The ACE-FTS ozone reveals a high bias of up to $40 \%$ in the comparison with non-coincident aircraft data in the upper troposphere (Hegglin et al., 2007). Papers detailing the validation studies for version 2.2 products (including the updated ozone, see Dupuy et al., 2008) will be available in a special issue of Atmos. Chem. Phys. on validation of ACE. 


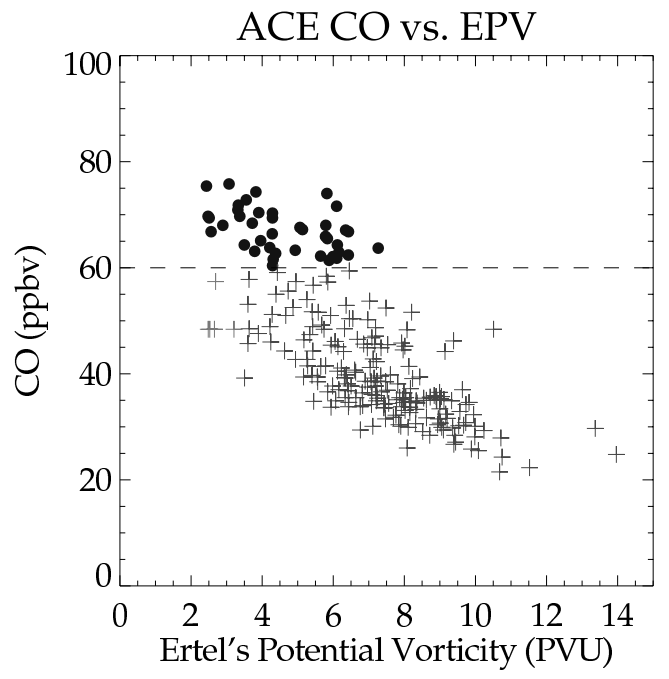

Fig. 2. Scatter plot of ACE CO $(16.5 \mathrm{~km})$ versus Ertel's potential vorticity (EPV) at $100 \mathrm{hPa}$ calculated from the NCEP/NCAR reanalysis data between $20^{\circ}-40^{\circ} \mathrm{N}$ latitude. High $\mathrm{CO}(\geq 60 \mathrm{ppbv})$ values are marked as dots and low $\mathrm{CO}(<60 \mathrm{ppbv})$ values are shown as pluses, respectively.

\section{Chemical isolation in the anticyclone}

Figure 1a shows $\mathrm{CO}$ mixing ratio amounts at $16.5 \mathrm{~km}$ for all of the ACE-FTS observations during June-August 20042006. The majority of points at mid to high latitudes lie in the stratosphere (where $\mathrm{CO} \leq 20$ parts per billion by volume, ppbv) and in the upper troposphere (where $\mathrm{CO}$ ranges 40 50 ppbv, see Clerbaux et al., 2005). There is a broad maximum in $\mathrm{CO}$ over the Asian monsoon region $\left(0^{\circ}-120^{\circ} \mathrm{E}\right.$ and $10^{\circ}-40^{\circ} \mathrm{N}$ ), and a similar maximum is evident for altitudes $\sim 12-20 \mathrm{~km}$ (not shown). HCN mixing ratios (Fig. 1b) also exhibit a maximum in this region, roughly coincident with the CO maximum. Daily observations of CO from MLS data have demonstrated that $\mathrm{CO}$ maxima at $100 \mathrm{hPa}(\sim 16 \mathrm{~km})$ occur within the Asian monsoon anticyclone throughout summer (Li et al., 2005; Park et al., 2007). Based on these previous observations, it is likely that the highest $\mathrm{CO}$ values seen in Fig. 1a represent individual ACE-FTS measurements within the anticyclone. To examine the behavior of other atmospheric constituents in the monsoon anticyclone, we use the $\mathrm{CO}$ values to identify profiles within the boundary of the anticyclone (i.e., the high values in Fig. 1a). Profiles "inside" are defined where $\mathrm{CO}$ is higher than $60 \mathrm{ppbv}$ between $0^{\circ}-$ $120^{\circ} \mathrm{E}$ and $10^{\circ}-40^{\circ} \mathrm{N}$ at $16.5 \mathrm{~km}$ (see Fig. 1a) and the rest of the profiles between $10^{\circ}-40^{\circ} \mathrm{N}$ are regarded as "outside" the anticyclone (representing background conditions). As an additional confirmation that these high $\mathrm{CO}$ values occur within the anticyclone, we calculated Ertel's potential vorticity (EPV) at the individual ACE observation locations using National Centers for Environmental Prediction/National Center for Atmospheric Research (NCEP/NCAR) reanalysis
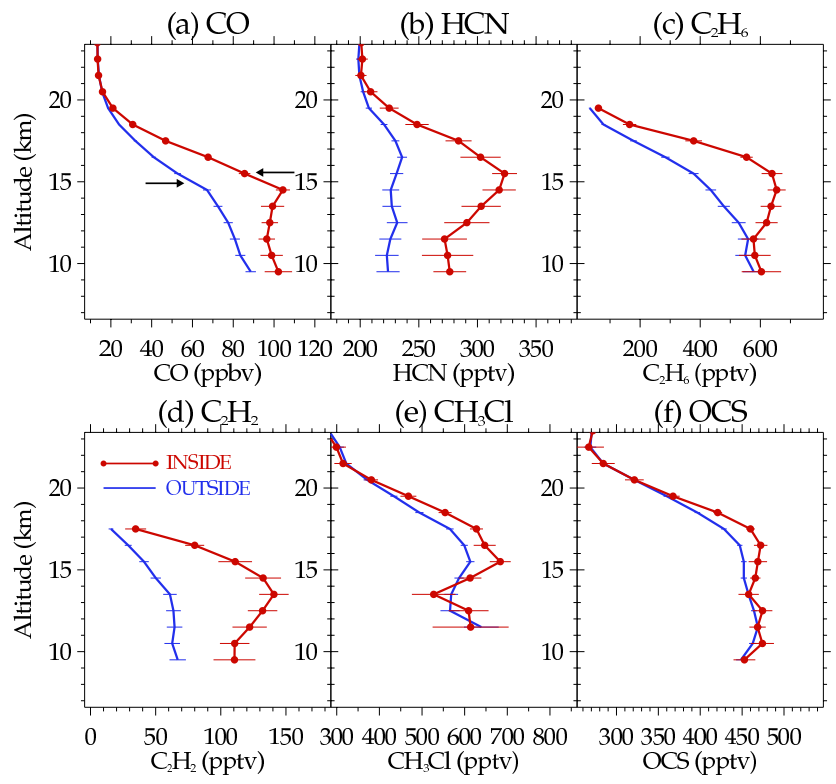

Fig. 3. Average profile of tropospheric tracers ((a) $\mathrm{CO}$, (b) $\mathrm{HCN}$, (c) $\mathrm{C}_{2} \mathrm{H}_{6}$, (d) $\mathrm{C}_{2} \mathrm{H}_{2}$, (e) $\mathrm{CH}_{3} \mathrm{Cl}$, and (f) OCS) inside (solid) and outside (dashed) of the monsoon anticyclone, respectively. Twosigma standard error from the mean is denoted as solid line.

data, and Fig. 2 shows a scatter plot of the CO-EPV relationship for all the observations over $20^{\circ}-40^{\circ} \mathrm{N}$. The monsoon anticyclone is in general characterized by a region of low EPV (Randel and Park, 2006). Figure 2 shows an overall anticorrelation between $\mathrm{CO}$ and $\mathrm{EPV}$, such that the high $\mathrm{CO}$ measurements (dots) are primarily associated with low EPV, i.e., near or within the anticyclone. Based on this definition, there are $\sim 40$ profiles inside and $\sim 240$ profiles outside the anticyclone for observations over June-August 2004-2006.

We compare in Fig. 3 the average vertical profiles of tropospheric constituents $\left(\mathrm{CO}, \mathrm{HCN}, \mathrm{C}_{2} \mathrm{H}_{6}, \mathrm{C}_{2} \mathrm{H}_{2}, \mathrm{CH}_{3} \mathrm{Cl}\right.$, and OCS) inside and outside of the anticyclone, respectively. For each group of profiles we calculate the mean and the standard error of the mean (the sample standard deviation, divided by the square root of the number of observations, shown as error bars in Fig. 3). Substantial enhancements within the anticyclone are observed for $\mathrm{CO}, \mathrm{HCN}, \mathrm{C}_{2} \mathrm{H}_{6}$, and $\mathrm{C}_{2} \mathrm{H}_{2}$ in Fig. 3, with significant differences up to $\sim 20 \mathrm{~km}$. While the outside or background profiles exhibit monotonic decreases with altitude, profiles inside the anticyclone show conspicuous maxima near $15 \mathrm{~km}$ for $\mathrm{CO}, \mathrm{HCN}$ and $\mathrm{C}_{2} \mathrm{H}_{6}$, and near $13 \mathrm{~km}$ for $\mathrm{C}_{2} \mathrm{H}_{2}$ (which has a significantly shorter lifetime, Table 1). The long-lived tracers $\left(\mathrm{CH}_{3} \mathrm{Cl}\right.$ and $\left.\mathrm{OCS}\right)$ show slight enhancements within the anticyclone over $\sim 14-18 \mathrm{~km}$ (Fig. 3e and f). The higher mixing ratios within the anticyclone probably result from a combination of rapid vertical transport and horizontal confinement ( $\mathrm{Li}$ et al., 2005; Randel and Park, 2006), and the elevated mixing ratios can be regarded as "fingerprints" of the near-surface pollutant concentrations. In 


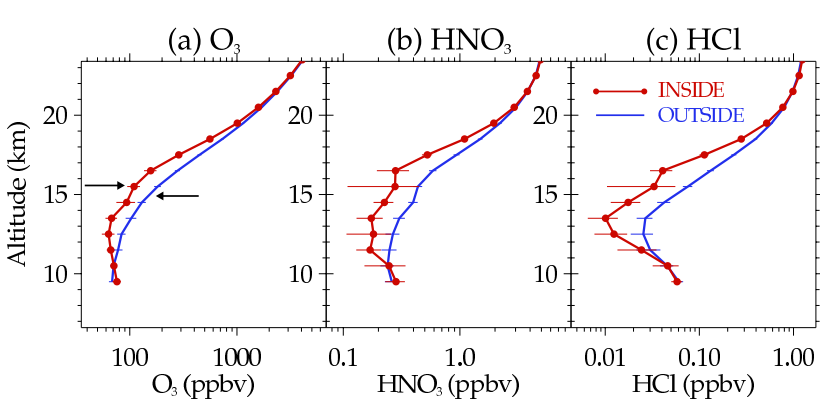

Fig. 4. Same as Fig. 3 but for stratospheric tracers $\left((\mathbf{a}) \mathrm{O}_{3}\right.$, (b) $\mathrm{HNO}_{3}$ and $\left.(\mathbf{c}) \mathrm{HCl}\right)$. Note the stratospheric tracers have log-scale $\mathrm{x}$-axis.

contrast, the outside or background profiles represent photochemically aged air, so that the inside-outside differences may be dependent on the lifetime of the individual species (as explored below). We note that the average mixing ratios shown in Fig. 3 are within the range of those obtained in aircraft field measurements in the lower and middle troposphere (Smyth et al., 1999; Blake et al., 1999; Singh et al., 2003; Xiao et al., 2007).

Figure 4 compares inside versus outside profiles for the stratospheric tracers $-\mathrm{O}_{3}, \mathrm{HNO}_{3}$ and $\mathrm{HCl}$. Each of these tracers shows reduced mixing ratios inside the anticyclone over $\sim 12-20 \mathrm{~km}$ compared to outside profiles, and this behavior is consistent with enhanced transport of tropospheric air into the anticyclone. These observations are consistent with the relative minimum in ozone within the anticyclone shown in Randel and Park (2006) and Park et al. (2007).

Tracer-tracer correlations are useful to diagnose air mass characteristics and relationships among different species. Figure 5 shows scatter plots of tropospheric tracers versus $\mathrm{CO}$, for $\mathrm{HCN}, \mathrm{C}_{2} \mathrm{H}_{6}, \mathrm{C}_{2} \mathrm{H}_{2}$, OCS, and $\mathrm{CH}_{3} \mathrm{Cl}$ (for data at $16.5 \mathrm{~km}$ ). Overall, each of the tropospheric tracers show strong correlations with $\mathrm{CO}$, with high $\mathrm{CO}$ values inside the anticyclone (orange plus signs) associated with high values of other species. $\mathrm{C}_{2} \mathrm{H}_{6}$ and $\mathrm{C}_{2} \mathrm{H}_{2}$ exhibit relatively compact correlations with $\mathrm{CO}$, suggesting similar sources for these species (Blake et al., 2003). There is significantly more scatter in the $\mathrm{HCN}$ versus $\mathrm{CO}$ diagram than other species (Fig. 5a), which is similar to results from the TRACE-P aircraft observations, and this may be a signature of different sources and sinks for HCN and CO (Singh et al., 2003). $\mathrm{CH}_{3} \mathrm{Cl}$ and $\mathrm{OCS}$ also exhibit some correlation with $\mathrm{CO}$, but relatively smaller differences between inside and outside profiles. Figure $5 \mathrm{f}$ shows a scatter plot for two stratospheric tracers $\left(\mathrm{HCl}\right.$ versus $\left.\mathrm{O}_{3}\right)$, showing a highly compact relationship. This occurs due mainly to the stratospheric chemical origin of the two species and long lifetime in the upper troposphere (Marcy et al., 2004). Low ozone inside the anticyclone is also correlated with high CO (not shown). The compact relationships between ozone and the other stratospheric tracers (e.g., $\mathrm{HF}$ and $\mathrm{HNO}_{3}$ ) are consistently found between 15 and $18 \mathrm{~km}$.
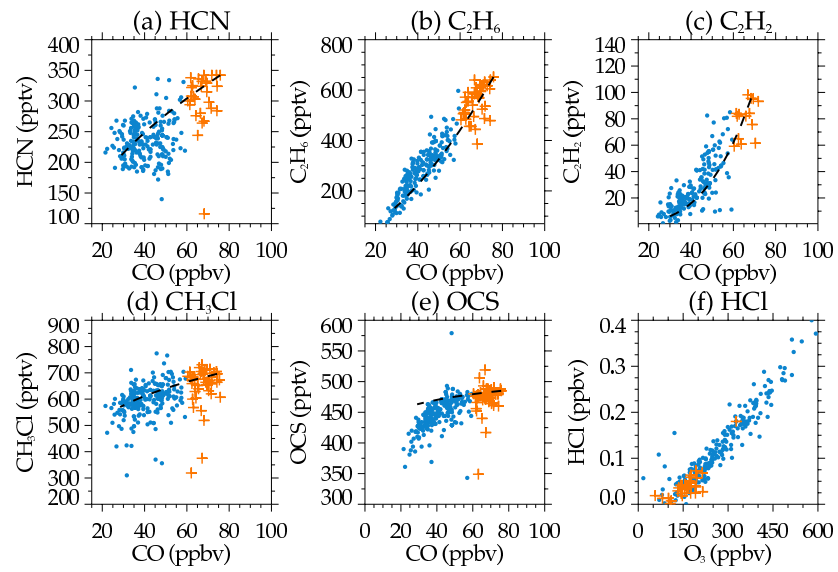

Fig. 5. Scatter plots of $\mathrm{CO}$ (ppbv) versus (a) $\mathrm{HCN}$ (pptv), (b) $\mathrm{C}_{2} \mathrm{H}_{6}$ (pptv), (c) $\mathrm{C}_{2} \mathrm{H}_{2}$ (pptv), (d) $\mathrm{CH}_{3} \mathrm{Cl}$ (pptv) and (e) OCS (pptv), and (f) $\mathrm{O}_{3}$ (ppbv) versus $\mathrm{HCl}$ (ppbv) at $16.5 \mathrm{~km}$. Pluses indicate measurements inside and dots indicate outside of the monsoon anticyclone, respectively. The dashed line in each panel is derived from the photochemical lifetimes of each species (see text for detail).

The compact linear relationships among $\mathrm{CO}, \mathrm{C}_{2} \mathrm{H}_{6}$ and $\mathrm{C}_{2} \mathrm{H}_{2}$ in Fig. 5 are consistent with common sources from biomass burning. In this case chemical loss is the primary mechanism that determines the slope of the scatter plots, which in turn is related to the relative chemical lifetimes of the species (Ehhalt et al., 1998). We test this in a simple way, by including a line in the scatter plots associated with the respective e-folding time of the two species assuming $\chi_{i}=\chi_{0} \times \exp \left(-\tau_{c o} / \tau_{i}\right)$. Here $\chi_{i}$ represents the $i$ th chemical species, $\chi_{0}$ represents the initial concentration, $\tau_{c o}$ and $\tau_{i}$ are the chemical lifetimes of $\mathrm{CO}$ and the $i$ th chemical species, respectively. The initial concentrations are set to be the maxima for $\mathrm{CO}$ and the $i$ th species, $\tau_{c o}$ is fixed as 2.5 months, and the other $\tau_{i}$ lifetimes are taken as the mean values from Table 1. These slopes for each of the tropospheric tracers are included in Fig. 5. Note that these slopes are linear on a log-log plot (Ehhalt et al., 1998), but appear logarithmic on the linear axes in Fig. 5. Overall there is quite reasonable agreement between the theoretical curves and the observed distributions for both $\mathrm{C}_{2} \mathrm{H}_{6}$ and $\mathrm{C}_{2} \mathrm{H}_{2}$ versus $\mathrm{CO}$. As noted above, there is significantly more scatter in the $\mathrm{HCN}$ versus $\mathrm{CO}$ distribution (and likewise for $\mathrm{CH}_{3} \mathrm{Cl}$ versus $\mathrm{CO}$ ), probably signifying distinct sources, but the overall distribution follows the respective slopes calculated from the lifetimes. For OCS, there is less agreement with the theoretical curve, but the application of such an idealized model is questionable for such a long lifetime (over 4 years for OCS). However, the overall good agreement with theory for the other tropospheric tracers is consistent with the differences between air inside and outside the anticyclone being primarily a result of relatively young air inside versus photochemically aged air outside. Also, the agreement in slopes is consistent with the approximate lifetimes of the constituents as listed in Table 1 . 


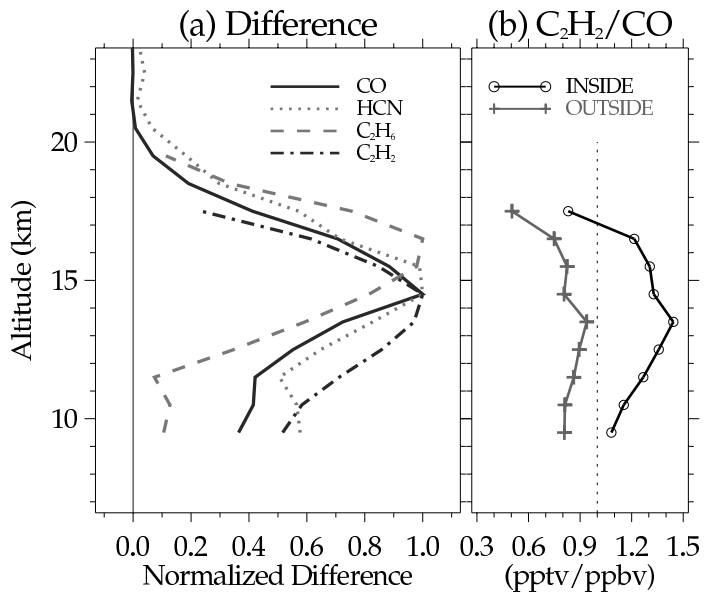

Fig. 6. (a) Normalized difference between average profiles inside and outside the anticyclone for the tropospheric tracers, i.e., $\mathrm{CO}$ (solid), $\mathrm{HCN}$ (dotted), $\mathrm{C}_{2} \mathrm{H}_{6}$ (dashed), and $\mathrm{C}_{2} \mathrm{H}_{2}$ (dash dot). (b) Ratio of $\mathrm{C}_{2} \mathrm{H}_{2} / \mathrm{CO}$ inside (open circle) and outside (plus) the anticyclone, respectively.

In order to compare the average vertical profiles inside and outside the anticyclone among the species, we calculate the differences between the mean profiles in Fig. 3, and then normalize the differences for each tropospheric constituent to a maximum value of 1.0 (Fig. 6a). Here we focus on the species $\mathrm{CO}, \mathrm{HCN}, \mathrm{C}_{2} \mathrm{H}_{6}$, and $\mathrm{C}_{2} \mathrm{H}_{2}$, which show the largest enhancements in Fig. 3. The tracer differences in Fig. 6a have maxima near $15 \mathrm{~km}$, and the exact altitudes of maximum values differ somewhat among the tracers $(\sim 15 \mathrm{~km}$ for $\mathrm{CO}$ and $\mathrm{HCN}, \sim 17$ for $\mathrm{C}_{2} \mathrm{H}_{6}$ and $\sim 13 \mathrm{~km}$ for $\mathrm{C}_{2} \mathrm{H}_{2}$ ), although the significance of these differences is unclear given the $\sim 3 \mathrm{~km}$ vertical resolution of the ACE-FTS data. We also include in Fig. $6 \mathrm{~b}$ the ratio of $\mathrm{C}_{2} \mathrm{H}_{2} / \mathrm{CO}$ for the inside and outside profiles, as an indicator of the relative age of an air mass (Smyth et al., 1999; Xiao et al., 2007). The typical range of the ratio is $0.2-2.2$ (pptv/ppbv), consistent with the data in Fig. 6b, and a ratio less than one indicates photochemically aged and well-mixed air (Talbot et al., 1999). The $\mathrm{C}_{2} \mathrm{H}_{2} / \mathrm{CO}$ ratio inside the anticyclone in Fig. $6 \mathrm{~b}$ is larger than one, indicating relatively young air transported up to $\sim 16 \mathrm{~km}$. The ratio is less than one outside the anticyclone, signifying photochemically aged and well-mixed air mass as the background.

The level of enhancement inside the anticyclone with respect to the background can be defined as $\Delta[X] /[X]_{\text {outside }} 5100$, where $[X]$ represent the constituent mixing ratio and $\Delta[X]$ is $[X]_{\text {inside }}-[X]_{\text {outside }}$ (see Coheur et al., 2007). The enhancement of tropospheric tracers inside the anticyclone is compared in Fig. 7 for different altitudes, plotted as a function of lifetime of the respective species. The enhancement is larger for the shorter-lived constituents and also systematically increases with altitude for $\mathrm{C}_{2} \mathrm{H}_{2}, \mathrm{C}_{2} \mathrm{H}_{6}$ and CO. The $\mathrm{C}_{2} \mathrm{H}_{2}$ level increases up to $190 \%$ in Fig. 7 and it can be as large as $2200 \%$ for a young biomass burning

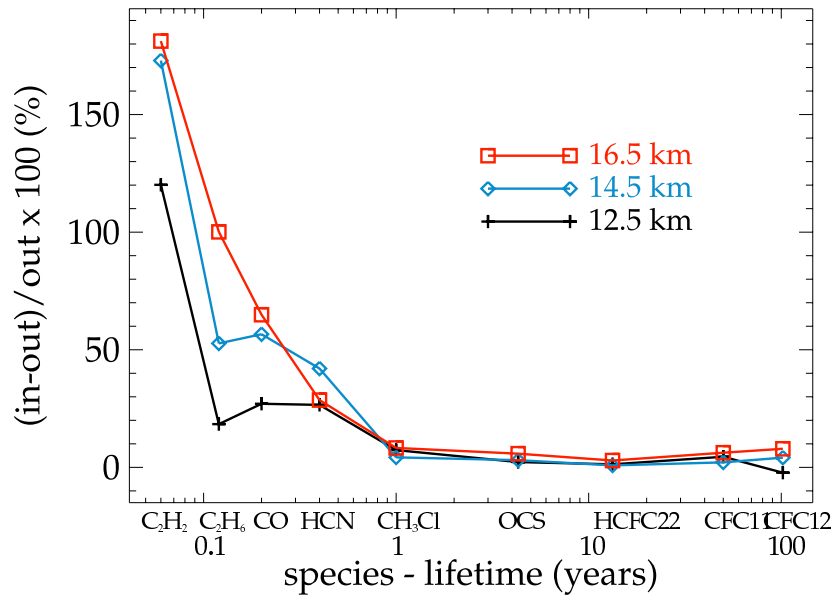

Fig. 7. Level of enhancement $(\%)$ of the nine tropospheric tracers at $12.5,14.5$ and $16.5 \mathrm{~km}$. The $\log$-scale $\mathrm{x}$-axis represents the chemical lifetime of the tracers in years $\left(\mathrm{CH}_{3} \mathrm{Cl}-1\right.$ year $)$.

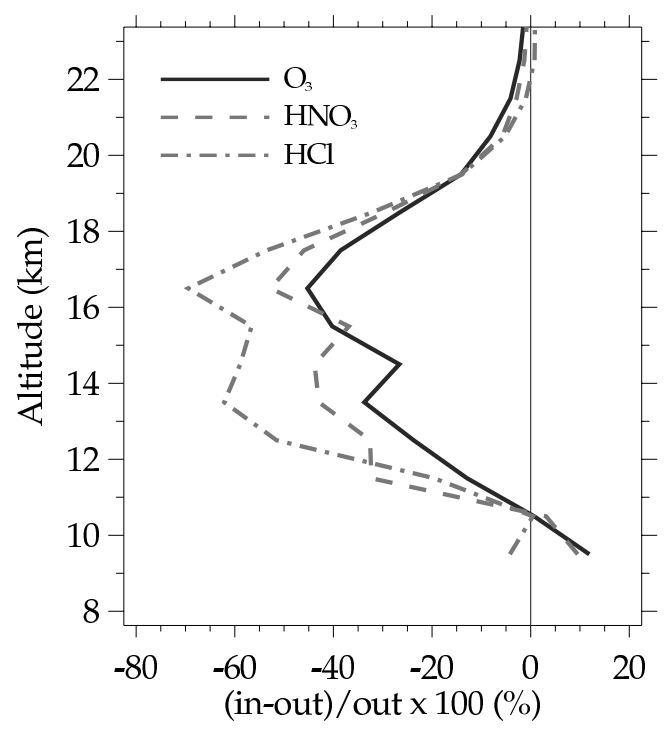

Fig. 8. Level of enhancement (\%) of the stratospheric tracers, $\mathrm{O}_{3}$ (solid), $\mathrm{HNO}_{3}$ (dashed), and $\mathrm{HCl}$ (dash dot).

plume (Coheur et al., 2007). The overall increased enhancement for shorter lifetimes is consistent with relatively young air inside the anticyclone, and older air in the background (as implied for the distributions seen in Fig. 5). There is also a systematic increase in enhancement with altitude over 12 $17 \mathrm{~km}$ for the shorter-lived species; this may be a signature of systematically older air with higher altitude for the outside or background profiles.

Figure 8 shows the level of enhancement for the stratospheric tracers. Here the values are negative because these tracers are depleted within the anticyclone as shown in Figs. 4 and 5. There are systematic decreases in the stratospheric tracers over $\sim 11-20 \mathrm{~km}$, with $\mathrm{O}_{3}$ and $\mathrm{HNO}_{3}$ 


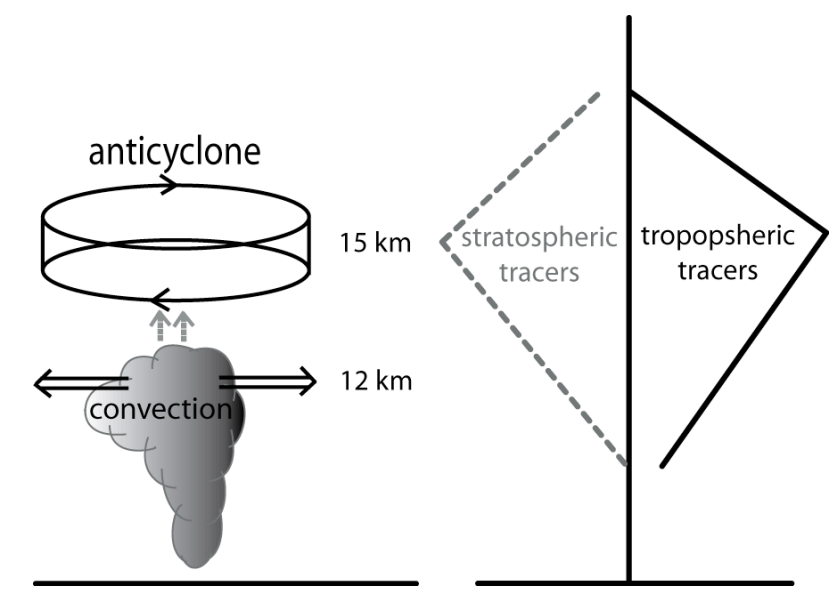

Fig. 9. Schematic diagram showing (left) level of maximum convective outflow $(\sim 12 \mathrm{~km})$ versus monsoon anticyclonic circulation $(\sim 15 \mathrm{~km})$. (Right) Level of maximum increase (decrease) in the tropospheric (stratospheric) tracers.

decreases up to $\sim 40 \%$ and $\mathrm{HCl}$ decreases near $\sim 60 \%$. The vertical profiles of these changes are consistent with the tropospheric tracer enhancement seen in Fig. 6a, and the stratospheric tracers provide further evidence of transport of lower tropospheric air to altitudes near and above the tropopause.

\section{Summary and discussion}

The Asian summer monsoon circulation acts as a transport barrier to the chemical species from upper troposphere to lower stratosphere during NH summer (Li et al., 2005; Randel and Park, 2006; Park et al., 2007). Due to vertical transport from deep convection and strong isolation within the anticyclone, chemical constituents often show relative maxima or minima over the monsoon region. In this study, we show further evidence of chemical isolation in the anticyclone using chemical constituents observed by the ACEFTS for the period covering summer (June-August) of 20042006. ACE-FTS data allow study of constituents with a variety of photochemical lifetimes, and provide information on the detailed vertical structure within the anticyclone.

$\mathrm{CO}$ vertical profiles show significant enhancement over the monsoon anticyclone from $\sim 12-20 \mathrm{~km}$ altitude. The $\mathrm{HCN}$ profiles show maxima almost in the same region as $\mathrm{CO}$. Using the clear signal of high $\mathrm{CO}$ (Fig. 1a), we define profiles to be "inside" the anticyclone where $\mathrm{CO}$ is higher than the threshold ( $60 \mathrm{ppbv}$ at $16.5 \mathrm{~km}$ ) and term "outside" the anticyclone to be the rest of the observations over the latitude band $10^{\circ}-40^{\circ} \mathrm{N}$. The observations with enhanced $\mathrm{CO}$ are associated with relatively low potential vorticity (Fig. 2), consistent with the region of the anticyclone. The selection of "inside" profiles is not very sensitive to the threshold CO values chosen in this study. Averaged profiles inside the anticy- clone show strong enhancements for the tropospheric tracers $\mathrm{CO}, \mathrm{HCN}, \mathrm{C}_{2} \mathrm{H}_{6}$, and $\mathrm{C}_{2} \mathrm{H}_{2}$ over approximately $10-20 \mathrm{~km}$ (Figs. 3 and 6), with relative maxima near $15 \mathrm{~km}$ (somewhat lower for $\mathrm{C}_{2} \mathrm{H}_{2}$ ). Relatively weak enhancements inside the anticyclone near $15 \mathrm{~km}$ are also observed for $\mathrm{CH}_{3} \mathrm{Cl}$ and OCS. There are corresponding decreases in stratospheric tracers $\left(\mathrm{O}_{3}, \mathrm{HNO}_{3}\right.$ and $\left.\mathrm{HCl}\right)$ inside the anticyclone over the same altitude range (Figs. 4 and 8 ).

The maxima (minima) in the tropospheric (stratospheric) constituents over $13-15 \mathrm{~km}$ may suggest that this is the altitude of strongest outflow from deep convection in the monsoon region. However, this altitude is somewhat higher than the maximum convective outflow level $(\sim 12 \mathrm{~km})$ inferred from tropical radiative balance (Folkins and Martin, 2005) or cloud height estimates (Gettelman et al., 2002; Liu and Zipser, 2005). Figure 9 shows a schematic diagram illustrating the vertical profiles of the circulation features in the monsoon region compared with the tracer profiles identified in this study. The right panel of Fig. 9 shows the level of maximum increase (decrease) in the tropospheric (stratospheric) tracers, which is close to $\sim 15 \mathrm{~km}$. The left panel highlights the main convective outflow level near $\sim 12 \mathrm{~km}$, with the strongest closed circulation of the anticyclone somewhat above this level ( $\sim 12-16 \mathrm{~km}$; Randel and Park, 2006). The mechanism(s) of vertical transport above $12 \mathrm{~km}$ are a subject of ongoing research, but likely involve large-scale circulation in the anticyclone (Park et al., 2007), overshooting deep convection (Dessler and Sherwood, 2004), or the dynamical divergence mechanism discussed in Folkins et al. (2007). Although the detailed mechanism(s) leading to formation and maintenance of the tracer profiles are not understood at present, the ACE-FTS data provide detailed observations to test idealized or more realistic models.

There exist substantial correlations between $\mathrm{CO}$ and the tropospheric tracers in the UTLS region. Compact correlations are found between $\mathrm{CO}$ and $\mathrm{C}_{2} \mathrm{H}_{6}$, and between $\mathrm{CO}$ and $\mathrm{C}_{2} \mathrm{H}_{2}$, suggesting common sources for these species. Somewhat higher scatter is observed between $\mathrm{CO}$ and $\mathrm{HCN}$, consistent with aircraft observations, and this may signify different sources for the two species. The observed slopes of the correlations among different tropospheric species are in reasonable agreement with calculations based on published lifetimes (Fig. 5), and this demonstrates that the differences between profiles inside and outside of the anticyclone are consistent with distinct photochemical ages. This conclusion is consistent with the ratio of $\left(\mathrm{C}_{2} \mathrm{H}_{2} / \mathrm{CO}\right)$ in Fig. $6 \mathrm{~b}$, which suggests relatively younger air inside the anticyclone.

The relative enhancements of tropospheric species inside the anticyclone are closely related to the photochemical lifetime of the species (Fig. 7). The largest enhancements are observed for species with the shortest lifetimes (namely $\mathrm{C}_{2} \mathrm{H}_{2}$ ), with relatively small differences found for lifetimes of 1 year or longer. The enhancements are also larger for higher altitudes (between 12 and $17 \mathrm{~km}$ ), and this may reflect the increase in photochemical age with altitude of species in the 
background atmosphere. Stratospheric tracers show a $\sim 40$ $60 \%$ decrease within the anticyclone over $\sim 11-20 \mathrm{~km}$ altitude range.

Acknowledgements. This work was partially supported under the NASA ACMAP and EOS programs. We thank Cathy Clerbaux and Ken Bowman for discussions and comments on the manuscript. Funding for ACE is provided primarily by the Canadian Space Agency. The National Center for Atmospheric Research is operated by the University Corporation for Atmospheric Research under sponsorship of the National Science Foundation.

Edited by: M. G. Lawrence

\section{References}

Andreae, M. O. and Merlet, P.: Emission of trace gases and aerosols from biomass burning, Global Biogeochem. Cy., 15(4), 955-966, 2001.

Beer, R.: TES on the Aura Mission: Scientific Objectives, Measurements, and Analysis Overview, IEEE T. Geosci. Remote, 44, 1102-1105, 2006.

Bernath, P. F., McElroy, C. T., Abrams, M. C., et al.: Atmospheric Chemistry Experiment (ACE): Mission overview, Geophys. Res. Lett., 32, L15S01, doi:10.1029/2005GL022386, 2005.

Blake, N. J., Blake, D. R., Sive, B. C., et al.: Biomass burning emissions and vertical distribution of atmospheric methyl halides and other reduced carbon gases in the South Atlantic region, J. Geophys. Res., 101, 24 151-24 164, 1996.

Blake, N. J., Blake, D. R., Wingenter, O. W., et al.: Influence of southern hemispheric biomass burning on midtropopsheric distributions of nonmethane hydrocarbons and selected halocarbons over the remote South Pacific, J. Geophys. Res., 104, 16213$16232,1999$.

Blake, N. J., Blake, D. R., Simpson, I. J., et al.: NMHCs and halocarbons in Asian continental outflow during the Transport and Chemical Evolution over the Pacific (TRACE-P) Field Campaign: Comparison With PEM-West B, J. Geophys. Res., 108(D20), 8806, doi:10.1029/2002JD003367, 2003.

Blake, N. J., Streets, D. G., Woo, J.-H., et al.: Carbonyl sulfide and carbon disulfide: Large-scale distributions over the western Pacific and emissions from Asia during TRACE-P, J. Geophys. Res., 109, D15S05, doi:10.1029/2003JD004259, 2004.

Boone, C. D., Nassar, R., Walker, K. A., Rochon, Y., McLeod, S. D., Rinsland, C. P., and Bernath, P. F.: Retrievals for the Atmospheric Chemistry Experiment Fourier Transform Spectrometer, Appl. Opt. 44, 7218-7231, 2005.

Chin, M. and Davis, D. D.: A reanalysis of carbonyl sulfide as a source of stratospheric background sulfur aerosol, J. Geophys. Res., 100(D5), 8993-9006, doi:10.1029/95JD00275, 1995.

Clerbaux, C., Hadji-Lazaro, J., Turquety, S., Mégie, G., and Coheur, P.-F.: Trace gas measurements from infrared satellite for chemistry and climate applications, Atmos. Chem. Phys., 3, 14951508, 2003, http://www.atmos-chem-phys.net/3/1495/2003/.

Clerbaux, C., Coheur, P. -F., Hurtmans, D., Barret, B., Carleer, M., Colin, R., Semeniuk, K., McConnell, J. C., Boone, C., and Bernath, P.: Carbon monoxide distribution from the ACE-
FTS solar occultation measurements, Geophys. Res. Lett., 32, L16S01, doi:10.1029/2005GL022394, 2005.

Clerbaux, C., George, M., Turquety, S., Walker, K. A., et al.: CO measurements from the ACE-FTS satellite instrument: data analysis and validation using ground-based, airborne and spaceborne observations, Atmos. Chem. Phys. Discuss., 7, 15 277-15340, 2007.

Coheur, P.-F., Herbin, H., Clerbaux, C., Hurtmans, D., Wespes, C., Carleer, M., Turquety, S., Rinsland, C. P., Remedios, J., Hauglustaine, D., Boone, C. D., and Bernath, P. F.: ACE-FTS observation of a young biomass burning plume: first reported measurements of $\mathrm{C}_{2} \mathrm{H}_{4}, \mathrm{C}_{3} \mathrm{H}_{6} \mathrm{O}, \mathrm{H}_{2} \mathrm{CO}$ and PAN by infrared occultation from space, Atmos. Chem. Phys., 7, 5437-5446, 2007, http://www.atmos-chem-phys.net/7/5437/2007/.

Connors, V. S., Gormsen, B. B., Nolf, S., and Reichle, H. G., et al.: Spaceborne observations of the global distribution of carbon monoxide in the middle troposphere during April and October 1994, J. Geophys. Res., 104, 21 455-21 470, 1999.

Deeter, M. N., Emmons, L. K., Edwards, D. P., Gille, J. C., and Drummond, J. R.: Vertical resolution and information content of CO profiles retrieved by MOPITT, Geophys. Res. Lett., 31, L15112, doi:10.1029/2004GL020235, 2004.

Dessler A. E. and Sherwood, S. C.: Effect of convection on the summertime extratropical lower stratosphere, J. Geophys. Res., 109, D23301, doi:10.1029/2004JD005209, 2004.

Dethof, A., O’Neill, A., Slingo, J. M., and Smit, H. G. J.: A mechanism for moistening the lower stratosphere involving the Asian summer monsoon, Q. J. Roy. Meteor. Soc., 125, 1079-1106, 1999.

Dufour, G., Boone, C. D., Rinsland, C. P., and Bernath, P. F.: First space-borne measurements of methanol inside aged southern tropical to mid-latitude biomass burning plumes using the ACE-FTS instrument, Atmos. Chem. Phys., 6, 3463-3470, 2006, http://www.atmos-chem-phys.net/6/3463/2006/.

Dupuy, E., Walker, K. A., J. Kar, J., et al.: Validation of ozone measurements from the Atmospheric Chemistry Experiment (ACE), Atmos. Chem. Phys. Discuss., 8, 2513-2656, 2008, http://www.atmos-chem-phys-discuss.net/8/2513/2008/.

Edwards, D. P., Emmons, L. K., Gille, J. C., Chu, A., et al.: Satellite-observed pollution from Southern Hemisphere biomass burning, J. Geophys. Res., 111, D14312, doi:10.1029/2005JD006655, 2006.

Ehhalt, D. H., Rohrer, F., Wahner, A., Prather, M. J., and Blake, D. R.: On the use of hydrocarbons for the determination of tropospheric OH concentrations, J. Geophys. Res., 103(D15), 18981 18 998, 10.1029/98JD01106, 1998.

Folkins, I., and Martin, R.: The vertical structure of tropical convection and its impact on the budgets of water vapor and ozone, J. Atmos. Sci., 62, 1560-1573, 2005.

Folkins, I., Fueglistaler, S., Lesins, G., and Mitovski, T.: A lowlevel circulation in the tropics, J. Atmos. Sci., accepted, 2007.

Fu, R., Hu, Y., Wright, J. S., Jiang, J. H., Dickinson, R. E., Chen, M., Filipiak, M., Read, W. G., Waters, J. W., and Wu, D. L.: Short circuit of water vapor and polluted air to the global stratosphere by convective transport over the Tibetan Plateau, Proc. Nat. Acad. Sci., 103, 5664-5669, 2006.

Gettelman, A., Salby, M. L., and Sassi, F.: Distribution and influence of convection in the tropical tropopause region, J. Geophys. Res., 107(D10), 4080, doi:10.1029/2001JD001048, 2002. 
Hegglin, M. I., Bernath, P. F., Boone, C. D., Daffer, W. H., Hoor, P., Manney, G. L., Schiller, C., Strong, K., and Walker, K. A.: Validation of ACE-FTS satellite data in the upper troposphere/lower stratosphere (UTLS) using non-coincident measurements, Atmos. Chem. Phys. Discuss., 7, 13 861-13 882, 2007.

Jacob, D. J., Crawford, J. H., Kleb, M. M., Connors, V. S., Bendura, R. J., Raper, J. L., Sachse, G. W., Gille, J. C., Emmons, L., and Heald, C. L.: The Transport and Chemical Evolution over the Pacific (TRACE-P) aircraft mission: design, execution, and first results, J. Geophys. Res., 108(D20), 1-19, 2003.

Krishnamurti, T. N. and Bhalme, H. N.: Oscillations of a monsoon system. Part I. Observational aspects, J. Atmos. Sci., 33, 19371954, 1976.

Li, Q., Jacob, D. J., Bey, I., Yantosca, R. M., Zhao, Y., Kondo, Y., and Notholt, J.: Atmospheric hydrogen cyanide $(\mathrm{HCN})$ : Biomass burning source, ocean sink?, Geophys. Res. Lett., 27, 357-360, 2000.

Li, Q., Jiang, J. H., Wu, D. L., Read, W. G., Livesey, N. J., Waters, J. W., Zhang, Y., Wang, B., Filipiak, M. J., Davis, C. P., Turquety, S., Wu, S., Park, R. J., Yantosca, R. M., and Jacob, D. J.: Trapping of Asian pollution by the Tibetan anticyclone: A global CTM simulation compared with EOS MLS observations, Geophys. Res. Lett., 32, L14826, doi:10.1029/2005GL022762, 2005.

Liu, C. and Zipser, E. J.: Global distribution of convection penetrating the tropical tropopause, J. Geophys. Res., 110, D23104, doi:10.1029/2005JD006063, 2005.

Logan, J. A., Prather, M. J., Wofsy, S. C., and McElroy, M. B.: Tropospheric chemistry - A global perspective, J. Geophys. Res., 86, 7210-7254, 1981.

Marcy, T. P., Fahey, D. W., Gao, R. S., Popp, P. J., Richard, E. C., Thompson, T. L., Rosenlof, K. H., Ray, E. A., Salawitch, R. J., Atherton, C. S., Bergmann, D. J., Ridley, B. A., Weinheimer, A. J., Loewenstein, M., Weinstock, E. M., Mahoney, M. J.: Quantifying Stratospheric Ozone in the Upper Troposphere with in Situ Measurements of $\mathrm{HCl}$, Science, 9, 304, 261-265, doi: 10.1126/science.1093418, 2004.

Park, M., Randel, W. J., Gettelman, A., Massie, S. T., and Jiang, J. H.: Transport above the Asian summer monsoon anticyclone inferred from Aura MLS tracers, J. Geophys. Res, 112, D16309, doi:10.1029/2006JD008294, 2007.

Randel, W. J. and Park, M.: Deep convective influence on the Asian summer monsoon anticyclone and associated tracer variability observed with Atmospheric Infrared Sounder (AIRS), J. Geophys. Res., 111, D12314, doi:10.1029/2005JD006490, 2006.
Rinsland, C. P., Dufour, G., Boone, C. D., Bernath, P. F., and Chiou, L.: Atmospheric Chemistry Experiment (ACE) measurements of elevated Southern Hemisphere upper tropospheric $\mathrm{CO}$, $\mathrm{C}_{2} \mathrm{H}_{6}, \mathrm{HCN}$, and $\mathrm{C}_{2} \mathrm{H}_{2}$ mixing ratios from biomass burning emissions and long-range transport, Geophys. Res. Lett., 32, L20803, doi:10.1029/2005GL024214, 2005.

Singh, H. B., Salas, L., Herlth, D., Kolyer, R., Czech, E., Viezee, W., Li, Q., Jacob, D. J., Blake, D., Sachse, G., Harward, C. N., Fuelberg, H., Kiley, C. M., Zhao, Y., and Kondo, Y.: In situ measurements of $\mathrm{HCN}$ and $\mathrm{CH}_{3} \mathrm{CN}$ over the Pacific Ocean: Sources, sinks, and budgets, J. Geophys. Res., 108(D20), 8795, doi:10.1029/2002JD003006, 2003.

Smyth, S., Bradshaw, J., Sandholm, S., et al.: Comparison of free tropospheric western Pacific air mass classification schemes for the PEM-West A experiment, J. Geophys. Res., 101, 1743-1762, 1996.

Smyth, S., Sandholm, S., Shumaker, B., et al.: Characterization of the chemical signatures of air masses observed during the PEM experiments over the western Pacific, J. Geophys. Res., 104, 16 243-16 254, 1999.

Talbot, R. W., Dibb, J. E., Scheuer, E. M., Blake, D. R., Blake, N. J., Gregory, G. L., Sachse, G. W., Bradshaw, J. D., Sandholm, S. T., and Singh, H. B.: Influence of biomass combustion emissions on the distribution of acidic trace gases over the southern Pacific basin during Austral springtime, J. Geophys. Res., 104, 56235634, 1999.

Watts, S. F.: The mass budgets of carbonyl sulfide, dimethyl sulfide, carbon disulfide and hydrogen sulfide, Atmos. Environ., 34, 761779, 2000.

Waters, J. W., Froidevaux, L., Harwood, R. S., et al.: The Earth Observing System Microwave Limb Sounder (EOS MLS) on the Aura satellite, IEEE T. Geosci. Remote, 44(5), 1075-1092, 2006.

Xiao Y., Jacob, D. J., and Turquety, S.: Atmospheric acetylene and its relationship with $\mathrm{CO}$ as an indicator of air mass age, J. Geophys. Res., 112, D12305, doi:10.1029/2006JD008268, 2007.

Yoshida, Y., Wang, Y., Zeng, T., and Yantosca, R.: A threedimensional global model study of atmospheric methylchloride budget and distributions, J. Geophys. Res., 109, D24309, doi:10.1029/2004JD004951, 2004.

Zhao, Y., Strong, K., Kondo, Y., Koike, M., Matsumi, Y., Irie, H., Rinsland, C. P., Jones, N. B., Suzuki, K., Nakajima, H., Nakane, H., and Murata, I.: Spectroscopic measurements of tropospheric $\mathrm{CO}, \mathrm{C}_{2} \mathrm{H}_{6}, \mathrm{C}_{2} \mathrm{H}_{2}$, and $\mathrm{HCN}$ in northern Japan, J. Geophys. Res., 107(D18), 4343, doi:10.1029/2001JD000748, 2002. 